\title{
ANALISIS NUMERIK PART BULKHEAD PADA SUB SYSTEM WING TO FUSELAGE JOINNER ASSEMBLY PESAWAT AEROBATIK MENGGUNAKAN METODE ELEMEN HINGGA
}

\author{
Enggar Kristian*.1, Agus Suprianto ${ }^{2}$, Nurhadi Pramana ${ }^{3}$, Sahril Afandi ${ }^{4}$, Endah Yuniarti ${ }^{5}$ \\ ${ }_{1,4,5}$ Prodi Teknik Penerbangan, Fakultas Teknologi Kedirgantaraan, Universitas Dirgantara Marsekal \\ Suryadarma \\ 2,3Pusat Teknologi Industri Pertahanan dan Keamanan, Badan Pengkajian dan Penerapan Teknologi \\ *Corrresponding Author: enggarkristian@gmail.com
}

\begin{abstract}
Abstrak - Analisis rancangan bulkhead dilakukan untuk memperoleh geometri terbaik untuk mencari berat yang efisien dengan mengubah geometri bentuk pada bulkhead yang merupakan sub system wing to fuselage untuk pesawat berkategori aerobatik dan berat yang optimal yang memenuhi persyaratan regulasi FAR 23 dan mengetahui respon distribusi tegangan, bending yang dihasilkan dan kriteria kegagalan struktur berdasarkan variasi geometri bentuk bulkhead. Pada penelitian ini untuk analisis statik bulkhead untuk pesawat berkategori aerobatik menggunakan material Aluminium Alloy 7075-T6 dan menggunakan metode pendekatan Schrenk untuk menghitung beban eksternal distrbusi gaya angkat pada sayap. Selain itu dilakukan proses optimisasi berat bulkhead berdasarkan metode pendekatan topologi yaitu perubahan geometri bentuk pada bulkhead untuk mereduksi berat, sudut insiden spar yang berbeda dan menghitung magin of safety. Proses penyelesaian masalah menggunakan perangkat lunak metode elemen hingga (Abaqus CAE). Optimisasi topologi pada part bulkhead sudut insidet $0^{\circ}$ dan $4^{\circ}$ menghasilkan volume yang berkurang pada benda sehingga mereduksi berat, tetapi nilai dari margin of safety $\mathrm{MS}=0$.
\end{abstract}

Kata Kunci: Bulkhead, Metode Elemen Hingga, Aluminium Alloy 7075-T6, Metode Pendekatan Schrenk, Optimisasi Topologi.

\begin{abstract}
The bulkhead design analysis was carried out to obtain the best geometry to find an efficient weight by changing the shape geometry of the bulkhead which is a subsystem of the wing to the fuselage for an aircraft categorized as aerobatics and an optimal weight that meets the requirements of FAR 23 regulations and sees the stress distribution response, the resulting bending and structural failure criteria based on the geometric variation of bulkhead shapes. In this study, to analyze the bulkhead static for an aerobatic category aircraft using Aluminum Alloy 7075-T6 material and using the Schrenk Approximation method to calculate the external distribution load of lift force on the wing. In addition, the optimization of bulkhead weight based on the topological approach method is to change the shape geometry of the bulkhead to reduce weight, in different spar incidents and calculate margin of safety. The problem solving process uses finite element method software (Abaqus CAE). Topological optimization of the bulkhead part with an incidence angle of $\mathrm{O}^{\circ}$ and $4^{\circ}$ results in a reduced volume of the object so that it reduces weight, but the value of the margin of safety $M S=0$.
\end{abstract}


Keywords: Bulkhead, Metode Elemen Hingga, Aluminium Alloy 7075-T6, Metode Pendekatan Schrenk, Optimisasi Topologi.

\section{LATAR BELAKANG}

Faktor utama yang perlu dipertimbangkan di pesawat terbang struktur adalah kekuatan, bobot, dan keandalan. Ini faktor menentukan persyaratan yang harus dipenuhi oleh setiap bahan yang digunakan untuk merancang pesawat. Rangka pada pesawat udara harus kuat dan ringan. Semua bahan yang digunakan untuk membuat pesawat harus bisa diandalkan. Keandalan meminimalkan kemungkinan kegagalan berbahaya dan tak terduga. Banyak gaya dan tegangan struktural bekerja pada sebuah pesawat saat terbang dan saat statis. Saat itu statis, gaya gravitasi menghasilkan berat. Selama penerbangan, manuver pun yang menyebabkannya percepatan atau perlambatan meningkatkan gaya dan menekankan pada sayap dan badan pesawat. Tekanan pada sayap pesawat udara adalah tegangan, tekan, geser, tekuk, dan torsi. Tekanan ini diserap oleh setiap komponen dari struktur sayap dan ditransmisikan ke badan pesawat struktur. Tegangan seperti ini dikenal sebagai beban, dan studi tentang beban disebut disebut analisis tegangan. Tegangan dianalisis dan dipertimbangkan saat pesawat dirancang.

Dalam penelitian ini dilakukan analisis numerik transformasi struktur wing dengan metode topologi optimalisasi dimana komponen ini merupakan komponen yang vital dalam keberhasilan proses pembuatan pesawat terbang tanpa awak. Optimasi topologi ini dilakukan dengan penggunakan perangkat lunak Abaqus $\mathrm{CAE}$, dimana fitur 2 Optimalisasi struktural menggunakan Abaqus adalah proses yang membantu untuk memperbaiki desain. Hasil optimasi struktural yang dirancang dengan baik akan menghasilkan komponen yang ringan, kaku, dan tahan lama. Abaqus menyediakan tiga pendekatan untuk optimasi struktural - optimasi topologi, optimasi bentuk, dan optimasi ukuran. Optimalisasi topologi dimulai dengan model awal dan menentukan desain optimal dengan memodifikasi properti material dalam elemen yang dipilih, secara efektif menghilangkan elemen dari analisis. Bentuk dan optimasi ukuran selanjutnya menyempurnakan model[ ${ }^{[1]}$.

\section{METODE PENELITIAN}

\subsection{Objek Penelitian}

Objek dari penelitian ini adalah jenis pesawat aerobatik yang pada penelitian ini menganalisis struktur wing. Gambar dibawah merupakan geometri dari pesawat aerobatik

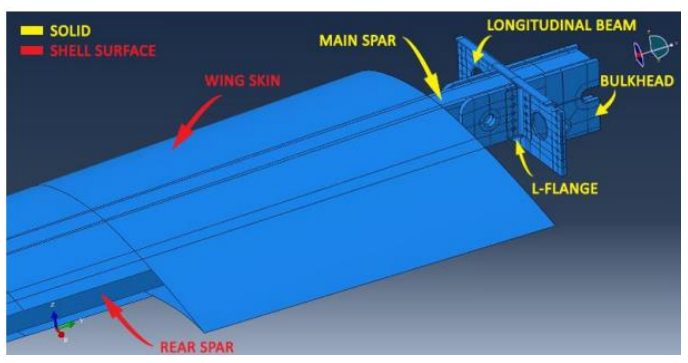

Gambar 2. 1 llustrasi Model Simulasi Wingto-Fuselage Joiner ${ }^{[2]}$

\subsection{Prosedur Penelitian}

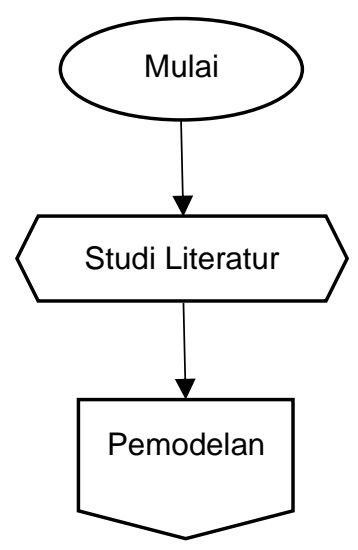




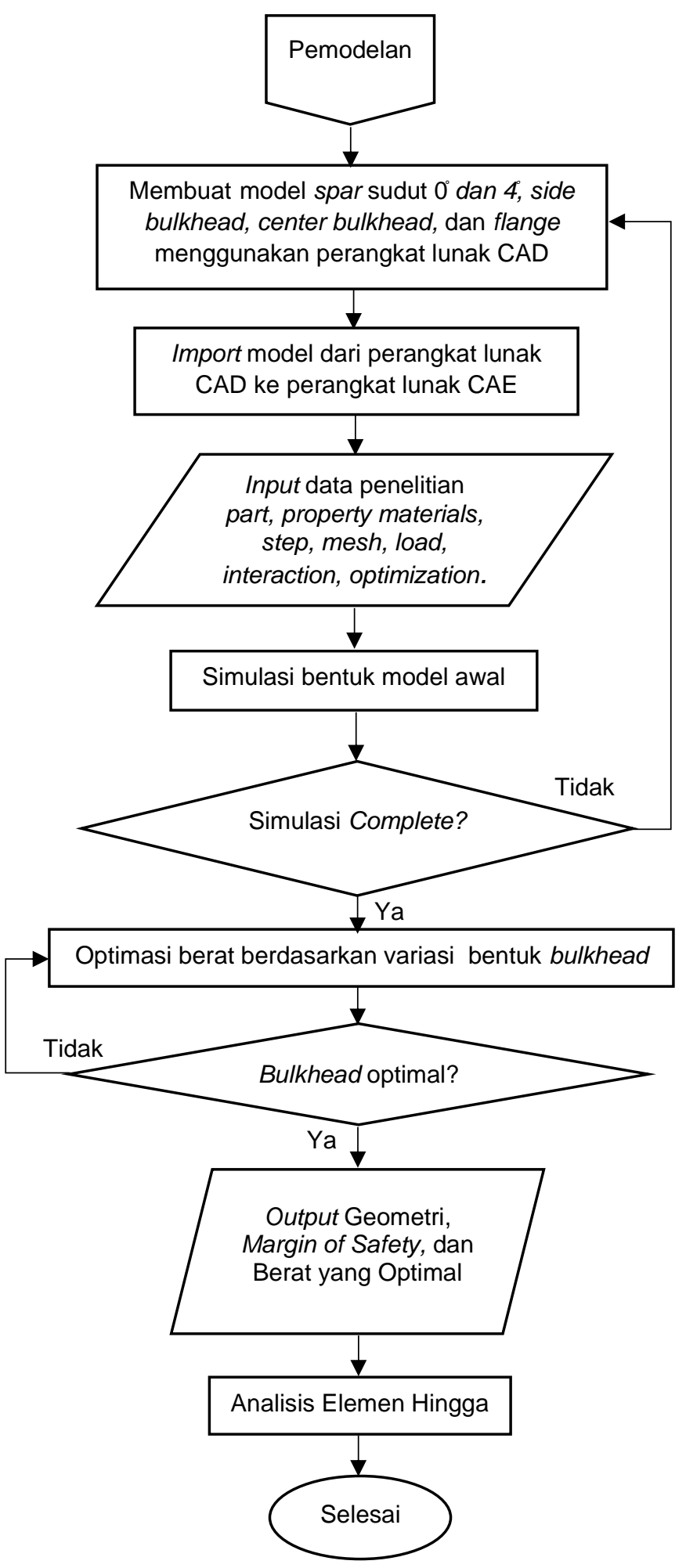

Gambar 2. 1 bagan diagram alir penelitian

\subsection{Sifat Mekanik Material}

Material yang digunakan dalam pengujian geometri struktur Bulkhead, Flange, dan Longitudinal Beam adalah Aluminium Alloy 7075-T6 dan Spar adalah komposit serat karbon dengan resin epoxy. Data-data tersebut diantaranya besaran kekuatan tarik pada arah fiber, kekuatan tarik pada arah tranversal, kekuatan tekan pada arah transversal, kekuatan tekan pada arah tranversal, dan kekuatan geser.

Tabel 2. 1 Sifat Mekanik Komposit Karbon Engineering Constant ${ }^{[2]}$

\begin{tabular}{|l|c|c|c|}
\hline \multicolumn{1}{|c|}{ Properties } & Simbol & Nilai & Satuan \\
\hline Young Modulus & $E_{1}$ & 77400 & $\mathrm{MPa}$ \\
\hline Young Modulus & $E_{2}$ & 72900 & $\mathrm{MPa}$ \\
\hline Young Modulus & $E_{3}$ & 72900 & $\mathrm{MPa}$ \\
\hline Poisson's ratio & $\mathrm{U}$ & 0.05 & - \\
\hline $\begin{array}{l}\text { Tensile stress } \\
\text { fiber direction }\end{array}$ & $\sigma_{T 1}$ & 912 & $\mathrm{MPa}$ \\
\hline $\begin{array}{l}\text { Compressive } \\
\text { stress fiber } \\
\text { direction }\end{array}$ & $\sigma_{C 1}$ & 862,5 & $\mathrm{MPa}$ \\
\hline $\begin{array}{l}\text { Tensile stress } \\
\text { transverse fiber } \\
\text { direction }\end{array}$ & $\sigma_{T 1}$ & 912 & $\mathrm{MPa}$ \\
\hline $\begin{array}{l}\text { Compressive } \\
\text { stress } \\
\text { transverse } \\
\text { direction }\end{array}$ & $\sigma_{c 1}$ & 862,5 & $\mathrm{MPa}$ \\
\hline Shear strength & $\tau_{12}$ & 89 & $\mathrm{Mpa}$ \\
\hline Density & $\mathrm{\rho}$ & $1,56 \mathrm{e}-6$ & tonne/mm \\
\hline Shear Modulus & $\mathrm{S}$ & 3150 & $\mathrm{MPa}$ \\
\hline
\end{tabular}

Tabel 2. 2 Sifat Mekanik Aluminium Alloy 7075-T6[2]

\begin{tabular}{|c|c|c|c|}
\hline Properties & Simbol & Nilai & Satuan \\
\hline Yield Stress & $\sigma$ & 462 & $\mathrm{MPa}$ \\
\hline Modulus & $\mathrm{E}$ & 71700 & $\mathrm{MPa}$ \\
\hline Poisson Ratio & $\mathrm{U}$ & 0,05 & - \\
\hline Density & $\rho$ & $2,81 \mathrm{e}-9$ & tonne $/ \mathrm{mm}^{3}$ \\
\hline
\end{tabular}

\subsection{Setup Simulasi}

\subsubsection{Module Part}

Struktur spar, bulkhead, L-flange, dan longitudinal beam pada struktur utama sayap Aerobatik dimodelkan menggunakan perangkat lunak dengan spesifikasi pemodelan yang ditunjukkan pada Tabel 2.3. 
Tabel 2. 3 Pemodelan part yang dianalisis

\begin{tabular}{|c|c|c|c|c|}
\hline \multirow{2}{*}{ Part } & \multirow{2}{*}{$\begin{array}{c}\text { Modeling } \\
\text { Space }\end{array}$} & \multirow{2}{*}{ Type } & \multicolumn{2}{|c|}{ Base Feature } \\
\cline { 4 - 5 } & Shape & Type \\
\hline Spar & $3 D$ & Deformable & Solid & Extrusion \\
\hline Bulkhead & $3 D$ & Deformable & Solid & Extrusion \\
\hline L-Flange & $3 D$ & Deformable & Solid & Extrusion \\
\hline $\begin{array}{c}\text { Longitudinal } \\
\text { beam }\end{array}$ & $3 D$ & Deformable & Solid & Extrusion \\
\hline
\end{tabular}

a. Spar

Part Spar ini adalah struktur utama dari wing yang menopang besar beban dari luar maupun beban dari dalam, namun pada analisis ini tidak berfokus pada part spar.

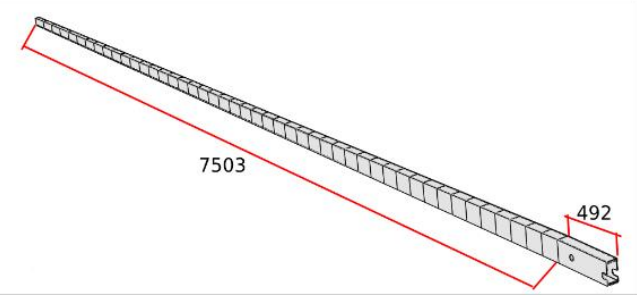

Gambar 2. 2 Part Spar Solid

\section{b. Bulkhead}

Part Bulkhead adalah objek utama dalam penelitian ini terdapa 2 jenis bulkhead yang berbeda yaitu part bulkhead dengan sudut insiden $0^{\circ}$ dan part bulkhead dengan sudut insiden $4^{\circ}$.

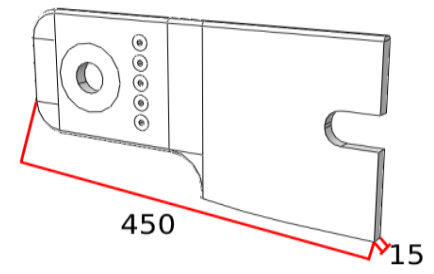

Gambar 2. 3 Part Front Bulkhead Solid dan Part Rear Bulkhead Solid dengan sudut insiden spar $0^{\circ}$

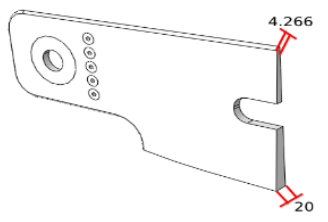

(a)

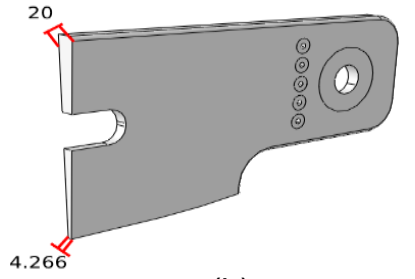

(b)

Gambar 2. 4 (a) Part Front Bulkhead Solid dengan sudut insiden spar $4^{\circ}$ (b) Part Rear Bulkhead Solid dengan sudut insiden spar $4^{\circ}$

\section{c. L-Flange}

Part L-Flange adalah 2 struktur pendukung untuk meengikat part bulkhead dan part longitudinal beam untuk mereduksi deformasi.

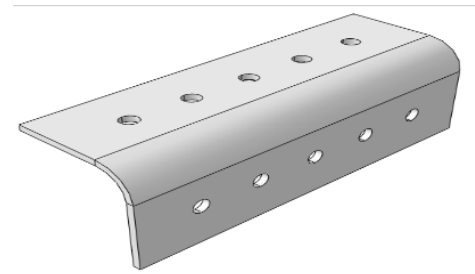

Gambar 2. 5 Part L-Flange Solid

\section{d. Longitudinal Beam}

Part Longitudinal Beam adalah struktur pembantu untuk mereduksi deformasi dari terikatnya longitudinal beam oleh L-flange.

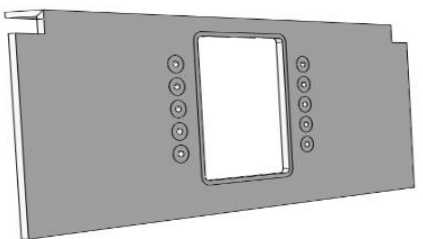

Gambar 2. 6 Part Longitudinal Beam Solid

\subsubsection{Module Property}

Material yang akan digunakan adalah Aluminium Alloy 7075-T6 menggunakan tipe isotropik dan Komposite Karbon menggunakan tipe engineering constant dengan orientasi sudut $0^{\circ}, 45^{\circ}, 0^{\circ},-45^{\circ}$. Pada part bulkhead, 
part L-flange dan part longitudinal beam menggunakan material Aluminium Alloy 7075-T6 dan pada spar menggunakan material Komposit Karbon. Properties dari material seperti Density, Young's Modulus, dan Poisson Ratio. Simulasi ini menggunakan kategori "Solid" dan "Homogenous".

\subsubsection{Module Assembly}

Module assembly berfungsi untuk menggabungkan beberapa part menjadi satu kesatuan bagian atau letak (instance) dan mengubah sudut jatuh (rotate) sehingga menjadi variasi simulasi.

Gambar 2. 8 Model keseluruhan tampak depan

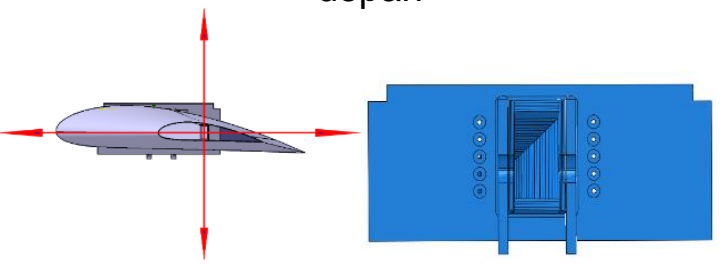

(a)

(b)

Gambar 2. 7 Model keseluruhan tampak samping sudut insiden $0^{\circ}$ (a) tip

(b) root

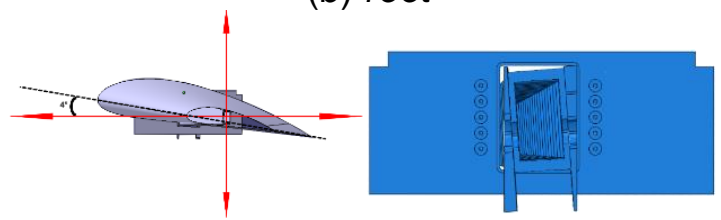

(a)

(b)

Gambar 2. 10 Model keseluruhan tampak samping sudut insiden $4^{\circ}$ (a) tip

(b) root

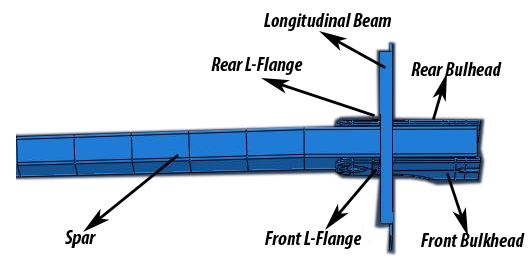

Gambar 2. 18 Model keseluruhan tampak atas

\subsubsection{Module Step}

Module step digunakan untuk menentukan langkah yang akan dilalui selama proses simulasi menggunakan step "Static, General' karena selama terjadi beban eksternal, part spar, part bulhead, part L-flange, dan part longitudinal beam pada struktur sayap mengalami perilaku statik di dalam struktur sayap yang tergabung spar, 2 bulkhead, 2 L-flange dan longitudinal beam dengan menyerap energi kinetik yang menyebabkan deformasi permanen. Periode waktu yang digunakan adalah "1".

\subsubsection{Module Interaction}

Module Interaction berfungsi untuk menentukan bidang kontak atau jenis interaksi yang dialami oleh model. Pada Constraint Manager pada simulasi ini dimaksudkan untuk menempelkan antara 2 benda atau lebih satu sama lain. Simulasi ini menggunakan Multi Point Constraint (MPC Pin), dan Multi Point Constraint (MPC Beam).

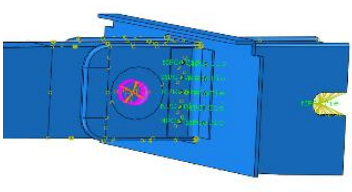

(a)

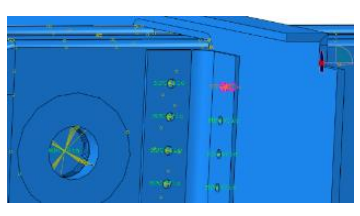

(c)

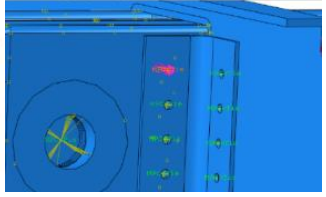

(b)

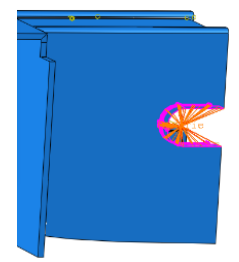

(d)
Gambar 3.12 Constraint Model (a) MPC $P I N$, (b) MPC BEAM, (c) MPC BEAM, (d) MPC PIN 
Keterangan:

- MPC PIN : Pilih Pin untuk menentukan sambungan yang disematkan antara setiap slave node dan titik kontrol.

- MPC BEAM : Pilih Beam untuk menentukan sambungan balok kaku untuk membatasi perpindahan dan rotasi setiap slave node ke perpindahan dan rotasi titik kontrol.

\subsubsection{Module Load}

Module load digunakan untuk menentukan jenis beban yang akan diberikan pada model. Pada simulasi ini mengambil referensi FAR 23, dengan cara menghitung beban memakai beban eksternal yang pada umumnya yang diapakai untuk mencari Distribusi Gaya Angkat yaitu Metode Pendekatan Schrenk dengan Structure Design Envelope sebagai berikut:

Tabel 2. 4 Stucture Design Envelope ${ }^{[8]}$

\begin{tabular}{|l|l|l|}
\hline $\begin{array}{l}\text { Structure Design } \\
\text { Envelope }\end{array}$ & Nilai & Satuan \\
\hline Chord Root & 1100 & $\mathrm{~m}$ \\
\hline Chord Tip & 460 & $\mathrm{~m}$ \\
\hline Tapper Ratio $(\lambda)$ & 0,418 & - \\
\hline Span (b) & 16 & $\mathrm{~m}$ \\
\hline PARTISI & 46 & - \\
\hline MTOW & 1300 & $\mathrm{~kg}$ \\
\hline L=W & 6376,5 & $\mathrm{~N}$ \\
\hline $\begin{array}{l}\text { LIMIT LOAD FACTOR } \\
\text { (UTILITY CATEGORY) } \mathrm{n}=\end{array}$ & 4,5 & - \\
\hline SAFETY OF FACTOR & 1,5 & - \\
\hline LIMIT LOAD & 28694,25 & $\mathrm{~N}$ \\
\hline ULTIMATE LOAD & 43041,38 & $\mathrm{~N}$ \\
\hline \multicolumn{2}{|c|}{ Metode sederhana } \\
\hline
\end{tabular}

mengetahui distribusi gaya angkat pada ialah metode schrenk. Metode Schrenk adalah sebuah metode perhitungan pendekatan (aproksimasi) yang digunakan untuk menghitung distribusi lift sepanjang span. Distribusi lift diperoleh dari rata-rata (mean) lift berdasarkan bentuk planform dan lift elliptica[[3].

$$
\begin{gathered}
L_{\text {planform }}=\frac{2 L}{(1+\lambda) b}\left[1+\left(\frac{2 y}{b}\right)(\lambda-1)\right] \\
(2.1) \\
L_{\text {eleptical }}=\frac{4 L}{\pi b} \sqrt{1-\left(\frac{2 y}{b}\right)^{2}} \\
(2.2) \\
L_{\text {Schrenk }}=\frac{L_{\text {planform }}+L_{\text {eleptical }}}{2}
\end{gathered}
$$

Dimana :

$\mathrm{b}=$ wing span $(\mathrm{m})$

$\mathrm{L}=$ gaya angkat $(\mathrm{N})$

$\mathrm{y}=$ jarak antar partisi $(\mathrm{m})$

$\lambda=$ aspect rasio

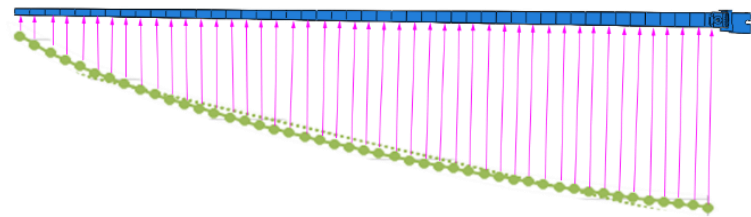

Gambar 2. 13 Penempatan Beban Schrenk pada 46 Partisi di Spar

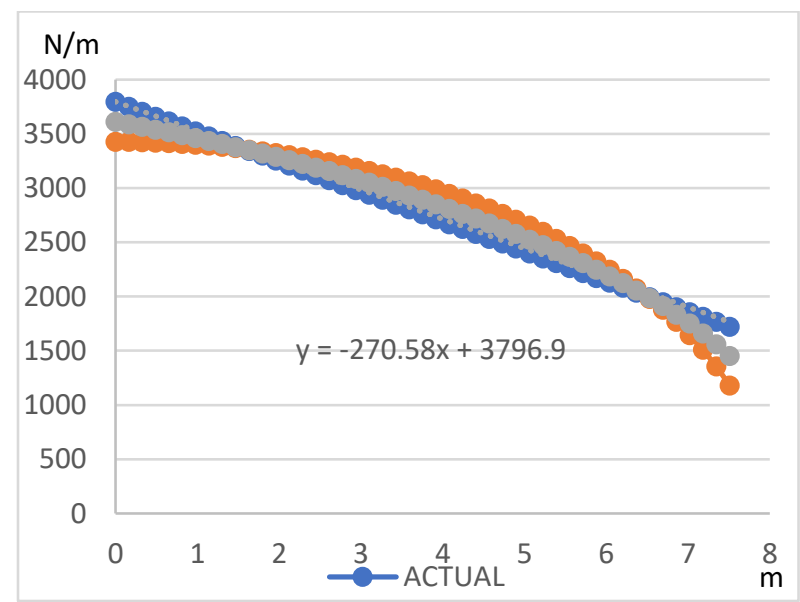

Gambar 2. 9 Grafik Schrenk Distribusi Gaya Angkat

Selain dapat menentukan jenis beban yang akan diberikan pada model, pada module "Load" dapat menentukan Boundary Condition atau kondisi batas. Boundary Condition yang dipilih adalah "ENCASTRE". 


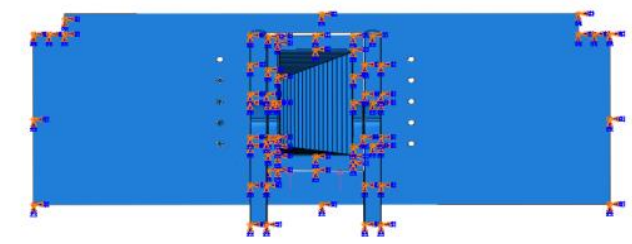

Gambar 2. 10 Boundary Condition

\subsubsection{Diskritisasi struktur (Meshing) dan pemilihan elemen}

Module Mesh digunakan untuk membuat model menjadi beberapa elemen dan titik. Simulasi ini menggunakan bentuk elemen" $H e x$ " teknik "structured" dan Teknik "sweep" dengan algoritma medial axis, dengan tatanan geometris "linear" dengan nilai "Seed" 1,0 - 10,0 pada Pendekatan bentuk global.

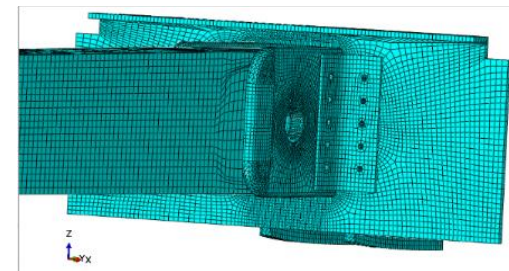

Gambar 2. 11 Mesh Assembly Model

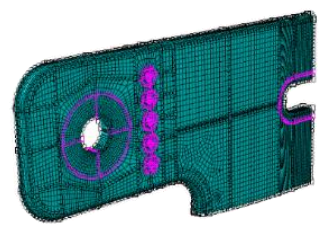

Gambar 2. 12 Mesh Part Bulkhead

Tabel 2. 5 Detail mesh pada Local Seed dengan penomoran

\begin{tabular}{|c|c|c|}
\hline Jenis Lubang & Approximate Element size & Satuan \\
\hline Hole Pin & 3 & $\mathrm{~mm}$ \\
\hline Hole Flange & 2 & $\mathrm{~mm}$ \\
\hline Hole Back Pin & 3 & $\mathrm{~mm}$ \\
\hline
\end{tabular}

Tabel 2. 6 Detail mesh pada pemodelan

\begin{tabular}{|c|c|c|c|c|}
\hline $\begin{array}{c}\text { Elements } \\
\text { dan } \\
\text { Nodes }\end{array}$ & Bulkhead & Spar & $\begin{array}{c}\text { Longitudinal } \\
\text { Beam }\end{array}$ & $\begin{array}{c}\text { L- } \\
\text { Flange }\end{array}$ \\
\hline
\end{tabular}

\begin{tabular}{|c|c|c|c|c|}
\hline $\begin{array}{c}\text { Total } \\
\text { number of } \\
\text { nodes }\end{array}$ & 62608 & 199808 & 18622 & 1472 \\
\hline $\begin{array}{c}\text { Total } \\
\text { number of } \\
\text { elements }\end{array}$ & 50938 & 162374 & 8788 & 656 \\
\hline
\end{tabular}

\subsubsection{Setup Simulasi Topologi Optimisasi}

Setelah Bulkhead dilakukan Metode Elemen Hingga kemudian masuk ketahap optimisasi pada Abaqus topology optimisasi modul, pada algorithma kondisi awal karena lebih efisien karena mencari solusi hingga mencapai jumlah siklus maksimum yaitu 15 iterasi, kemudian strain energy dan volume menjadi pilihan utama, sebagai batasan (constrain) bulkhead sudut insiden $0^{\circ}$ kurang dari sama dengan $95 \%$ dan bulkhead sudut insiden $45^{\circ}$ kurang dari sama dengan $60 \%$.

\subsubsection{Penentuan Geometri Pencabu-} $\tan$

Geometri Pencabutan ditentukan berdasarkan set, area sebagai batasan optimisasi yang dilakukan oleh abaqus topologi optimisasi modul, untuk mengetahui pola optimisasi yang dihasilkan dari Bulkhead, area yang harus dibatasi adalah partisi sekitar lubang sendi, lubang sendi Sebagai Daerah Terlarang yang mana tidak fokuskan pada optimisasi, abaqus mengabaikan kondisi lubang sendi.

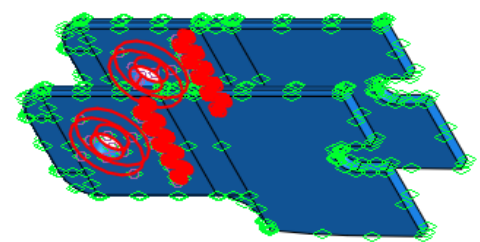

Gambar 2. 13 Geometri Pencabutan pada Lubang Sendi 


\section{HASIL DAN PEMBAHASAN 3.1 Analisis Statik Sebelum Optimisasi}

Analisis statik pada struktur Wing Aerobatik dengan menggunakan pendekatan metode elemen hingga telah dilakukan. Hasil pemilihan geometri part bulkhead $0^{\circ}$ dan part bulkhead $4^{\circ}$ dengan menggunakan material isotropic analisis statik adalah sebagai berikut.

\subsubsection{Part Bulkhead 0 ${ }^{\circ}$}

Pada inisial analisis statik part front bulkhead $0^{\circ}$ dan part rear bulkhead $0^{\circ}$ mendapatkan hasil distribusi tegangan $S$ Misses dilihat pada Gambar 3.1 Front Bulkhead $0^{\circ}$ tegangan maksimum pada slot lubang untuk joiner L-Flange dan struktur sebesar $462 \mathrm{MPa}$ dan Rear Bulkhead $0^{\circ}$ tegangan maksimum pada slot lubang untuk joiner L-Flange dan struktur sebesar $462 \mathrm{MPa}$. Tegangan maksimum yang dihasilkan sama dengan kegagalan dari material aluminium alloy 7075-T6, maka Margin of Safety dapat dihitung sebagai berikut:

$$
\begin{array}{r}
\text { Margin of Safety (MS) } \\
=\left(\frac{462}{462}\right)-1=0
\end{array}
$$

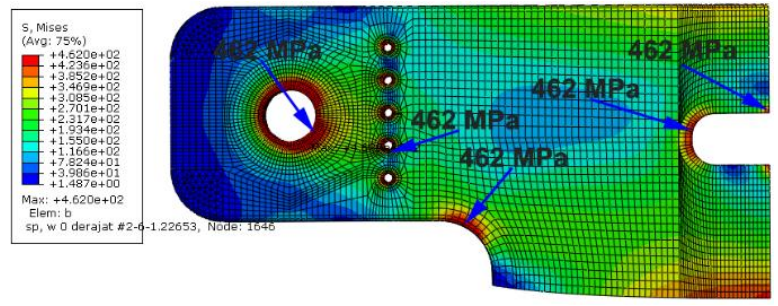

(a)

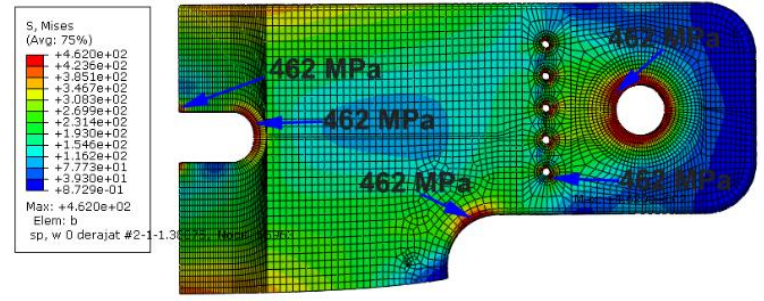

(b)
Gambar 3. 1 (a) Distribusi Tegangan pada Front Bulkhead $0^{\circ}$ (b) Distribusi Tegangan pada Rear Bulkhead $0^{\circ}$

\subsubsection{Part Bulkhead $4^{\circ}$}

Pada inisial analisis statik part front bulkhead $4^{\circ}$ mendapatkan hasil distribusi tegangan $S$ Misses dilihat pada Gambar 4.4 Front Bulkhead $4^{\circ}$ tegangan maksimum pada slot lubang untuk joiner L-Flange dan struktur sebesar $462 \mathrm{MPa}$ dan Rear Bulkhead $4^{\circ}$ tegangan maksimum pada slot lubang untuk joiner L-Flange dan struktur sebesar $462 \mathrm{MPa}$. Tegangan maksimum yang dihasilkan sama dengan kegagalan dari material aluminium alloy 7075-T6, maka Margin of Safety dapat dihitung sebagai berikut:

Margin of Safety (MS)

$$
=\left(\frac{462}{462}\right)-1=0
$$

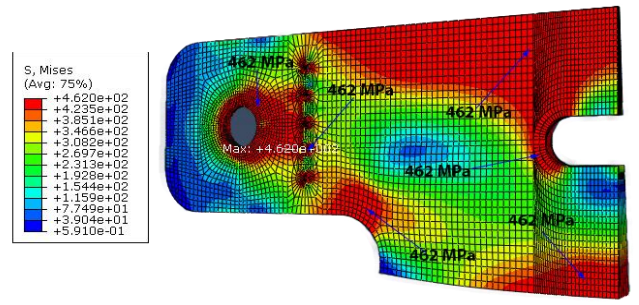

(a)

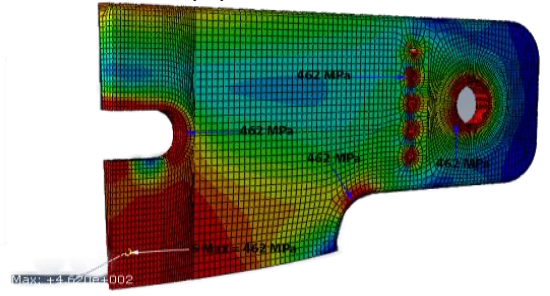

(b)

Gambar 3. 2 (a) Distribusi Tegangan pada Front Bulkhead $4^{\circ}$ (b) Distribusi Tegangan pada Rear Bulkhead $4^{\circ}$

\subsection{Optimisasi bulkhead}

Optimisasi topologi bulkhead dilakukan untuk mengetahui pattern yang dihasilkan, yang akan digunakan dalam proses uji dan analisis. 


\subsubsection{Optimisasi Topologi Part Bulkhead $0^{\circ}$}

Pada Gambar 3.4 dapat dilihat pola bulkhead yang dihasilkan dari proses optimiasi yang dilakukan. Pola tersebut digambar ulang untuk dilakukan analisis kekuatan struktur selanjutnya.

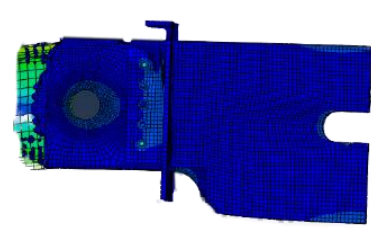

(a)

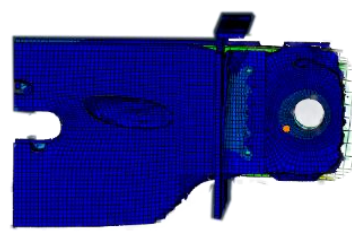

(b)
Gambar 3. 4 (a) Optimisasi Topologi Front Bulkhead $0^{\circ}$ (b) Optimisasi Topologi Rear Bulkhead $0^{\circ}$

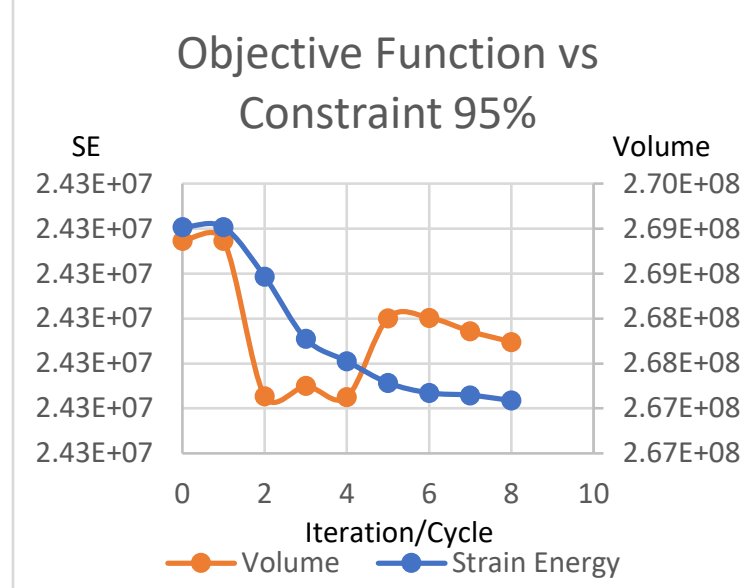

Gambar 3. 5 Grafik Strain Energy dan Volume terhadap proses iterasi dengan Constraint 95\%

Pada Gambar 3.5 dapat dilihat pola bulkhead yang dihasilkan dari proses optimiasi yang dilakukan. Pola tersebut digambar ulang untuk dilakukan analisis kekuatan struktur selanjutnya. Pada Gambar 3.5 terlihat grafik Strain energy sebagai fungsi objektif dan volume sebagai constrain, Strain Energy akan menurun pada iterasi 0 - 2 karena energi yang diserap belum terlalu besar, lalu meningkat pada iterasi ke 5 dikarenakan energi yang diserap bertambah seiring pengurangan volume yang direduksi ketika diberikan pembebanan selama proses iterasi, dan strain energy akan terus menurun jika volume sudah tidak berkurang dikarenakan beban yang diterima tidak mampu ditahan kembali oleh part bulkhead. Pengurangan volume sebesar $95 \%$ berdasarkan Set-up volume friction selama proses iterasi.

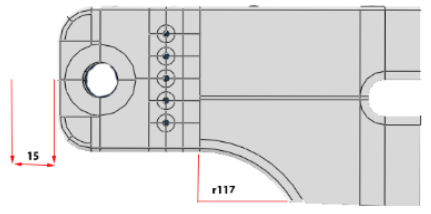

(a)

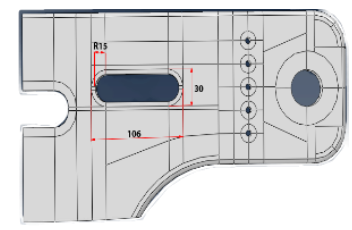

(b)
Gambar 3. 6 Adopsi pattern optimisasi pada (a) front bulkhead $0^{\circ}$ (b) rear bulkhead $0^{\circ}$

\subsubsection{Optimisasi Topologi Part Bulkhead 4}

Pada Gambar 4.11 dapat dilihat pola bulkhead yang dihasilkan dari proses optimisasi yang dilakukan. Pola tersebut digambar ulang untuk dilakukan analisis kekuatan struktur selanjutnya.

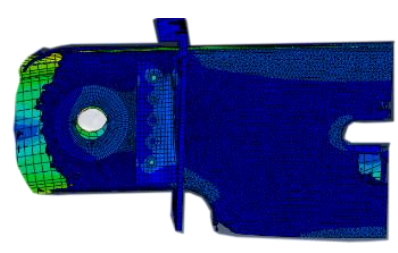

(a)

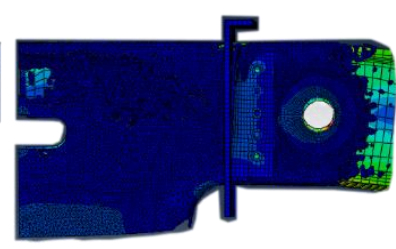

(b)
Gambar 3. 7 (a) Optimisasi Topologi Front Bulkhead $4^{\circ}$ (b) Optimisasi Topologi Rear Bulkhead $4^{\circ}$ 


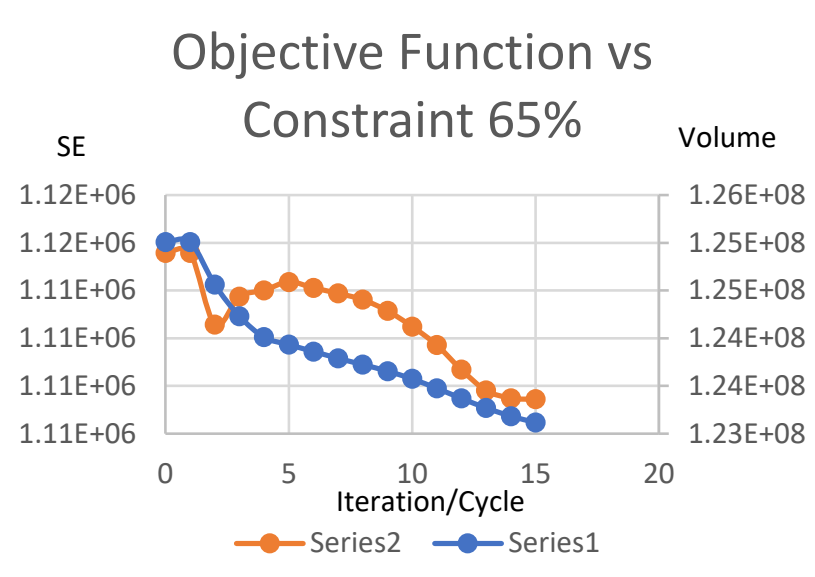

Gambar 3. 8 Grafik Strain Energy dan Volume terhadap proses iterasi dengan Constraint $65 \%$

Pada Gambar 3.8 dapat dilihat pola bulkhead yang dihasilkan dari proses optimiasi yang dilakukan. Pola tersebut digambar ulang untuk dilakukan analisis kekuatan struktur selanjutnya. Pada Gambar 3.8 terlihat grafik Strain energy sebagai fungsi objektif dan volume sebagai constrain, Strain Energy akan menurun pada iterasi $0-2$ karena energi yang diserap belum terlalu besar, lalu meningkat pada iterasi ke $3-5$ dikarenakan energi yang diserap bertambah seiring pengurangan volume yang direduksi ketika diberikan pembebanan selama proses iterasi, dan strain energy akan terus menurun jika volume sudah tidak berkurang dikarenakan beban yang diterima tidak mampu ditahan kembali oleh part bulkhead. Pengurangan volume sebesar 65\% berdasarkan Set-up volume friction selama proses iterasi.

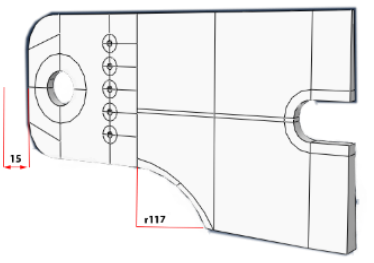

(a)

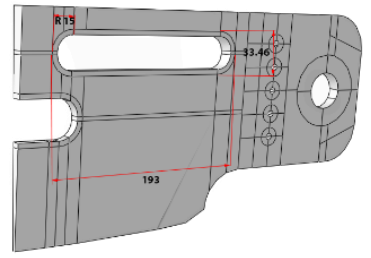

(b)
Gambar 3. 9 Adopsi pattern optimisasi pada (a) front bulkhead $4^{\circ}$ (b) rear bulkhead $4^{\circ}$

\subsection{Analisis Statik Hasil Optimisasi}

Pada Gambar 3.10 dapat dilihat pola bulkhead yang dihasilkan dari proses optimiasi yang dilakukan. Pola tersebut digambar ulang untuk dilakukan analisis kekuatan struktur selanjutnya.

\subsubsection{Part Bulkhead 0 ${ }^{\circ}$}

Pada analisis statik part front bulkhead $0^{\circ}$ setelah optimisasi topologi mendapatkan hasil distribusi tegangan $S$ Misses dilihat pada Gambar 3.10 Front Bulkhead $0^{\circ}$ tegangan maksimum pada slot lubang untuk back pin dan struktur sebesar $462 \mathrm{MPa}$, serta Rear Bulkhead $0^{\circ}$ sama tegangan maksimum pada slot lubang untuk back pin, struktur sebesar $462 \mathrm{MPa}$, dan pada struktur topologi yang dilubangi terdapat konsentrasi tegangan pada radius sudutnya sebesar $420 \mathrm{MPa}$ sampai $430 \mathrm{MPa}$, artinya mereduksi volume akan menambah distribusi tegangan pada struktur tersebut. Tegangan maksimum yang dihasilkan sama dengan kegagalan dari material aluminium alloy 7075-T6, maka Margin of Safety dapat dihitung sebagai berikut:

Margin of Safety (MS)

$$
=\left(\frac{462}{462}\right)-1=0 \text {. }
$$



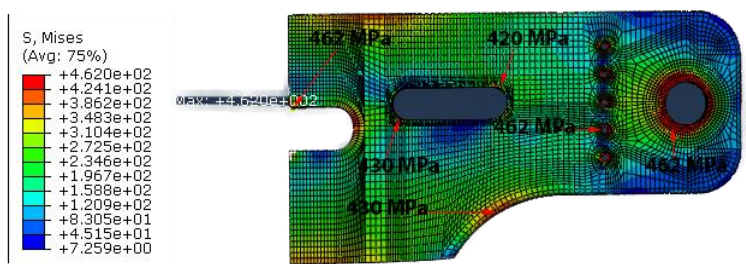

(a)
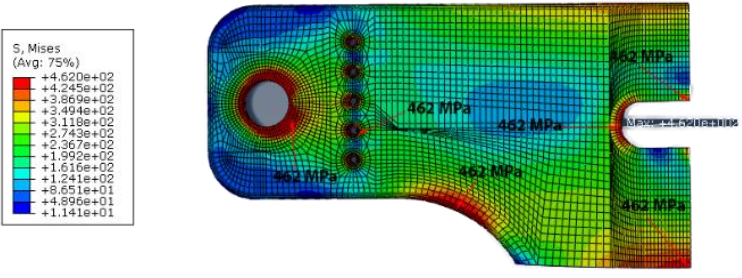

(b)

Gambar 3. 10 (a) Distribusi Tegangan pada Front Bulkhead $0^{\circ}$ setelah optimisasi (b) Distribusi Tegangan pada Rear Bulkhead $0^{\circ}$ setelah optimisasi

Tabel 3. 1 Hasil sebelum dan sesudah optimisasi

\begin{tabular}{|c|c|c|c|}
\hline $\begin{array}{c}\text { Kondisi } \\
\text { Part }\end{array}$ & $\begin{array}{c}\text { Berat, } \\
\mathbf{m} \text { (Kg) }\end{array}$ & $\begin{array}{c}\text { Tegangan, } \\
\text { S (MPa) }\end{array}$ & $\begin{array}{c}\text { Margin of } \\
\text { Safety, } \\
\text { MS }\end{array}$ \\
\hline Front Bulkhead 0 & 3,44 & 462 & 0 \\
\hline Rear Bulkhead 0 & 3,44 & 462 & 0 \\
\hline $\begin{array}{c}\text { Front Bulkhead 0 } \\
\text { setelah optimisasi }\end{array}$ & 3,08 & 462 & 0 \\
\hline $\begin{array}{c}\text { Rear Bulkhead 0 } \\
\text { setelah optimisasi }\end{array}$ & 2,96 & 462 & 0 \\
\hline
\end{tabular}

Pada Tabel 3.1 diketahui bahwa berat dari part bulkhead $0^{\circ}$ berhasil direduksi untuk Front Bulkhead $0^{\circ}$ sebelum dan sesudah dioptimisasi beratnya berkurang 3,44 kg - 3,08 kg = 0,36 kg dan untuk Rear Bulkhead $0^{\circ}$ sebelum dan sesudah dioptimisasi beratnya berkurang 3,44 kg - 2,96 kg = $0,48 \mathrm{~kg}$. Pada tegangan perancangan awal dan perancangan setelah dioptimisasi topologi tidak berubah atau sama yaitu $462 \mathrm{MPa}$, nilai tegangan tersebut sama dengan kegagalan material dari aluminium alloy 7075-T6 yang bernilai $462 \mathrm{MPa}$. Didapatkan Margin of Safety pada semua kondisi part adalah 0 .

\subsubsection{Part Bulkhead 4}

Pada analisis statik part front bulkhead $4^{\circ}$ setelah optimisasi mendapatkan hasil distribusi tegangan $S$ Misses dilihat pada Gambar 3.11 Front Bulkhead $4^{\circ}$ tegangan maksimum pada slot lubang untuk joiner L-Flange, pin, back pin dan struktur sebesar $462 \mathrm{MPa}$, serta Rear Bulkhead $4^{\circ}$ tegangan maksimum pada slot lubang untuk joiner L-Flange, pin, back pin, struktur sebesar $462 \mathrm{MPa}$ dan struktur pada topologi mendapatkan konsentrasi tegangan pada sudut radius $15 \mathrm{~mm}$ sebesar 430 $\mathrm{MPa}$ s/d $462 \mathrm{MPa}$. Stress maksimum yang dihasilkan sama dengan kegagalan dari material aluminium alloy 7075-T6, maka Margin of Safety dapat dihitung sebagai berikut:

$$
\begin{array}{r}
\text { Margin of Safety (MS) } \\
=\left(\frac{462}{462}\right)-1=0
\end{array}
$$

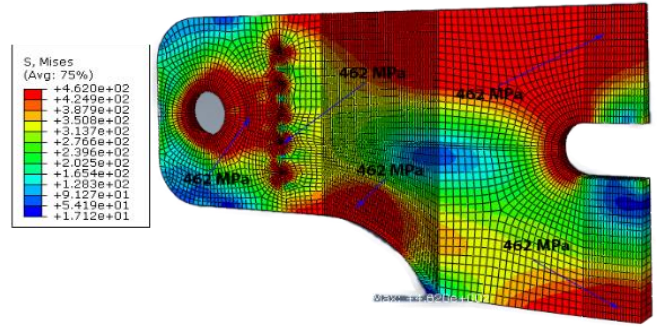

(a)

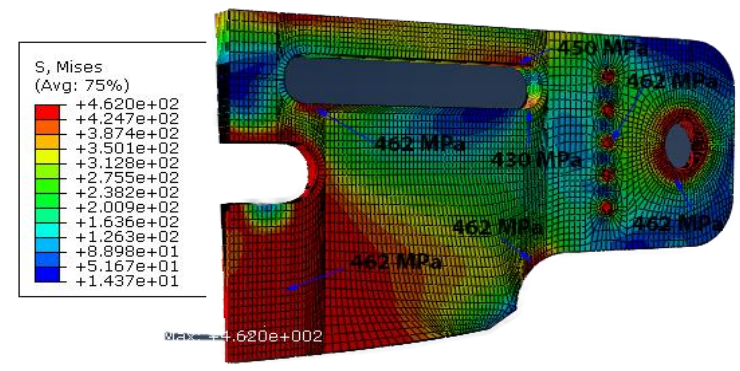

(b)

Gambar 3. 11 (a) Distribusi Tegangan pada Front Bulkhead $4^{\circ}$ setelah optimisasi (b) Distribusi Tegangan pada Rear Bulkhead $4^{\circ}$ setelah optimisasi 
Tabel 3. 2 Hasil sebelum dan sesudah optimisasi

\begin{tabular}{|c|c|c|c|}
\hline $\begin{array}{c}\text { Kondisi } \\
\text { Part }\end{array}$ & $\begin{array}{c}\text { Berat, } \\
\mathbf{m}(\mathbf{k g})\end{array}$ & $\begin{array}{c}\text { Tegangan, } \\
\text { S (MPa) }\end{array}$ & $\begin{array}{c}\text { Margin of } \\
\text { Safety, } \\
\text { MS }\end{array}$ \\
\hline Front Bulkhead 4 $^{\circ}$ & 2,61 & 462 & 0 \\
\hline Rear Bulkhead 4 & 3,06 & 462 & 0 \\
\hline $\begin{array}{c}\text { Front Bulkhead 4 } \\
\text { setelah optimisasi }\end{array}$ & 2,31 & 462 & 0 \\
\hline $\begin{array}{c}\text { Rear Bulkhead 4 } \\
\text { setelah optimisasi }\end{array}$ & 2,46 & 462 & 0 \\
\hline
\end{tabular}

Pada Tabel 3.2 diketahui bahwa berat dari part bulkhead $4^{\circ}$ berhasil direduksi untuk Front Bulkhead $4^{\circ}$ sebelum dan sesudah dioptimisasi beratnya berkurang 2,61 $\mathrm{kg}-2,31 \mathrm{~kg}=$ $0,30 \mathrm{~kg}$ dan untuk Rear Bulkhead $4^{\circ}$ sebelum dan sesudah dioptimisasi beratnya berkurang 3,06 kg - 2,46 kg = $0,60 \mathrm{~kg}$. Pada tegangan perancangan awal dan perancangan setelah dioptimisasi topologi tidak berubah atau sama yaitu $462 \mathrm{MPa}$, nilai tegangan tersebut sama dengan kegagalan material dari aluminiu alloy 7075-T6 yang bernilai $462 \mathrm{MPa}$. Didapatkan Margin of Safety pada semua kondisi part adalah 0.

\section{KESIMPULAN}

Berdasarkan pembahasan dan hasil analisa yang terdapat pada KESIMPULAN, maka dapat diambil beberapa kesimpulan sebagai berikut:

1. Distribusi stress tertinggi pada slot lubang untuk pin, back pin, dan L-flange pada bulkhead karena beban yang diterima oleh menitik beratkan pada pin dan joiner pada L-flange sehingga nilai stress yang berada pada bagian slot lubang memiliki nilai yang tinggi.

2. Masing - masing part bulkhead baik rancangan awal maupun setelah optimisasi Margin of Safety $\mathrm{MS}=0$. Dengan kata lain kegagalan rancangan sama dengan kegagalan material.

3. Pada analisis ini berhasil mereduksi berat pada Part Bulkhead sudut insiden $0^{\circ}$ dan Part Bulkhead sudut insiden $4^{\circ}$. Mereduksi berat dengan cara optimisasi topologi mendapatkan nilai sebagai berikut:

- Part Bulkhead $0^{\circ}$

Front Bulkhead : $3,44 \mathrm{~kg}$ $3,08 \mathrm{~kg}=0,36 \mathrm{~kg}$ dan Rear Bulkhead: $3,44 \mathrm{~kg}-2,96 \mathrm{~kg}=$ $0,48 \mathrm{~kg}$

- Part Bulkhead $4^{\circ}$

Front Bulkhead : $2,61 \mathrm{~kg}$ $2,31 \mathrm{~kg}=0,30 \mathrm{~kg}$ dan Rear Bulkhead : $3,06 \mathrm{~kg}-2,46 \mathrm{~kg}=$ $0,60 \mathrm{~kg}$

\section{DAFTAR PUSTAKA}

[1] Hans A. Eschenauer. Topology optimization of continuum structures: Areview. 2001.

[2] Laporan Wing Joiner BPPT. 2020. Finite Element Analysis Structure Wing to Fuselage Joiner Pesawat Tanpa Awak Medium Altitude Long Endurance (PTTA - MALE). Badan Pengkaji dan Penerapan Teknologi, Tangerang Selatan.

[3] Soemaryanto.A.R., dan Rosid.N.H. 2018. Verifikasi Metode Schrenk Dengan Simulasi CFD Berbasis Persamaan NavierStokes Dalam Analisis Pembebanan Sayap Pesawat Udara Nirawak Kelas Ringan. 2018. Lembaga Penerbangan dan Antariksa Nasional, Bogor.

[4] U.S. Department of Transportation Federal Aviation Administration, 2004, AIRFRAME GUIDE FOR CERTIFICATION OF $P A R T 23$ AIPLANES: United States. 
[5] Niu Yung Michael Cun. 1999. Airframe Stress Analysis and Sizing : Second Edition. Hongkong Conmilit Press Ltd, Hongkong

[6] Logan Daryl.L. 2007. A First Course in the Finite Element Method, Fourth Edition. University of Wisconsin, Platteville. Thomson.

[7] Rodrigo Benevides. 2011. Boosting the concept of topography optimized parts. Presentation; Altair HTC Congress.

[8] Badan Pengkaji Penerapan dan Teknologi. 2020. AA-SM-515-000 Loads - Simplified Part 23 Aircraft Loads. Perhitungan Excel. Tangerang. 